\title{
A study of the rural water supply-demand situation in South West Nigeria
}

\author{
O. Ojo \\ Department of Geography and Resource Management, \\ Osun State University, Okuku Campus, Nigeria, West-Africa
}

\begin{abstract}
The study examines the water supply-demand characteristics in selected rural communities in South West Nigeria. The issue of safe water availability and accessibility was also investigated. Primary data generated through the use of questionnaire. In addition, the study employed focus group discussion and key informant interview techniques targeted at relevant stakeholders to gather additional data and information which were analyzed using relevant statistical techniques.

The results showed that the water supply-demand situation of the area was characterized by a lot of water demand deficits with substantial percentage of the population being impacted by water shortages. The study attributed this partly to the absence of potable water supply in some of the rural communities as well as the below optimum performance of some of the water supply systems where they were available. The future water supply-demand characteristics of the area were also analyzed in relation to the projected population. The results showed that based on the current projection, there is likely to be a further worsening of the water supply-demand situation in the area unless some positive actions are embarked upon to improve the water supply systems. Based on the foregoing, the study highlighted some possible policy options aimed at addressing the issue of sustainable rural water supply in the study area.
\end{abstract}

Keywords: rural water supply availability and accessibility water demandsupply characteristics. 


\section{Introduction}

Access to safe water supply has been one of the recurring issues on the developmental agenda of many developing countries over the past three to four decades. The seriousness attached to the provision of safe water particularly in the face of rapidly increasing global population is underscored by the commitment of billions of dollars to the pursuit of the goal of "universal service"(USAID [4], ADB/UNO/HABITAT [1], Martisen [2]). Indeed, in realization of the strategic importance of save water availability and accessibility to environmental sustainability, 189 nations in September 2000, consented to the Millennium Development Goals (MDGs). Among these goals, MDG 7 (Environmental Sustainability), target 10 seeks to "halve by 2015 the proportion of people without sustainable access to safe drinking water and basic sanitation" (Madeleen and Kamminga [3]). In spite of increasing global awareness, the general consensus at the 2002 United Nations World Summit on Sustainable Development was that the current realities - as well as the situation expected in the near future - are far from that goal (The Economist Sept. 7-13, 2002 [5]).

The situation is particularly worrisome in Nigeria where less than half of the 140 million people have access to portable water (Ayoade [6], Ojo [7, 8]). Given the connection between water availability, sanitation and health, the need to address the challenges of sustainable water supply cannot be over emphasized. It is against this background that the current study examines the rural water supplydemand situation in south west Nigeria with particular emphasis on Osun state.

\section{The study area}

This study area covered 11 most vulnerable small towns located within seven (7) focal Local Government Areas of Osun state of south west Nigeria including; Ife Central, Olorunda, Ayedaade, Ejigbo, Odo Otin, Oriade and Ifedayo (LGAs) (Fig. 1) The State which is located in the Southwestern humid tropical zone of Nigeria was carved out of the old Oyo State in 1991.

According to the 2006 National Population Census, the state has an estimated population of 3,423,535 while the population of the 11 small towns is about 71, 092, making up 2.1 percent of Osun State total population. Osun State has 15 major water supply facilities thirteen of which are from surface water; one is from ground water while another one is from spring. The largest of the facilities is the Ede water scheme which has a total installed capacity of $160,000 \mathrm{~m}^{3} /$ day, but currently operating at a performance level of about $25 \%$. The plant covers locations scattered in up to 10 LGAs of the State (Osun State Report of the National Baseline Survey, 2007 [9]). Apart from this, there were many private/ public boreholes and hand dug wells that provide basic water requirements to the people of the State. 


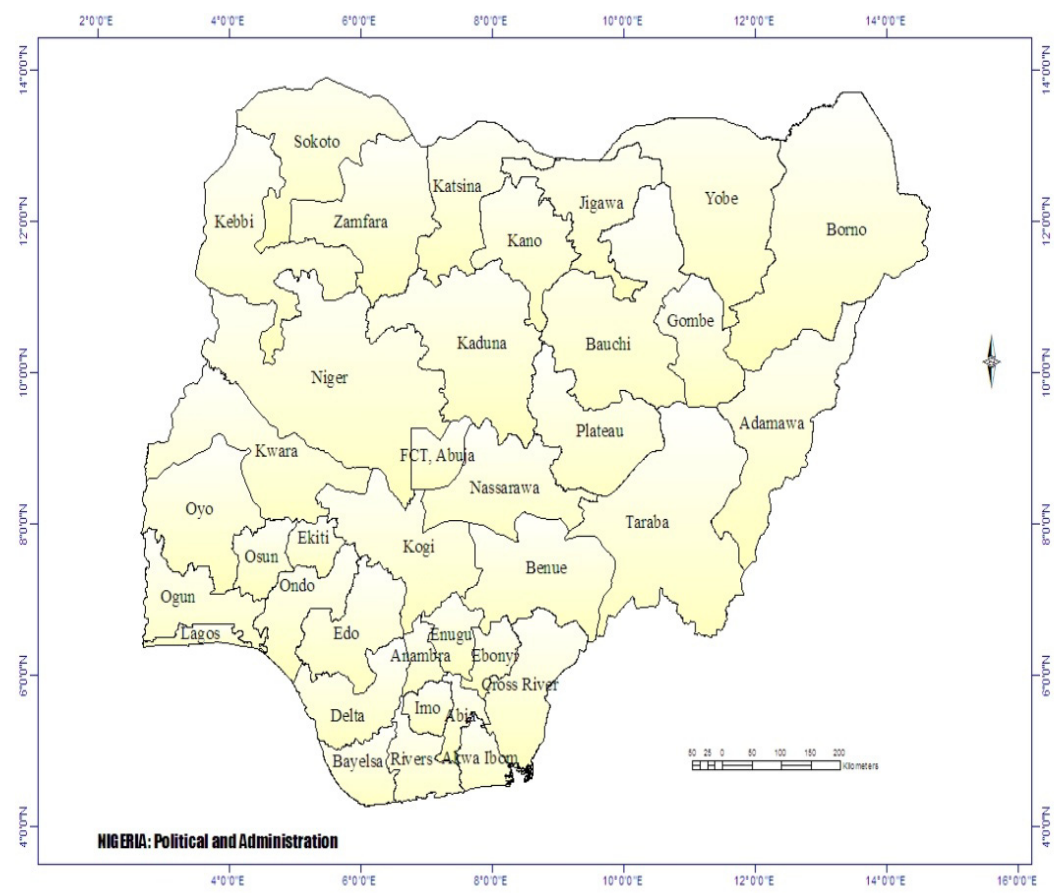

*South West Nigeria is comprised of Lagos, Oyo, Ogun, Osun, Ondo and Ekiti States.

Figure 1: Nigeria Political and Administrative Divisions [States*].

\section{Methodology and data collection}

\subsection{Methodology}

In addition to the application of basic statistical techniques, the production efficiency model was also employed in the analysis of data. The Production Efficiency Index (PEI) was employed in determining the level of capacity utilization of the water supply systems in the study area. The PEI relates the actual production of a water supply system to its maximum possible production potential (Ojo [10]). In quantitative terms the PEI can be expressed in the form;

$$
\mathrm{PEI}=100 \mathrm{P}_{\mathrm{a}} \mathrm{P}_{\mathrm{p}}^{-1}
$$

where PEI $=$ Production efficiency index

$\mathrm{P}_{\mathrm{a}}=$ Actual Production

$\mathrm{P}_{\mathrm{p}}=$ Potential Production

For the purpose of population projection, a growth rate of $2.83 \%$ was used in line with the recommendation of the National Population Commission (NPC), while a figure of 60 litres per person per day was used for computing water demand estimates based on the suggestion of the World Bank. 


\subsection{Sources and types of data}

The bulk of the data used in this study was purely primary, sourced through questionnaire and participatory observations on households. Data on population was obtained from the National Population Commission (NPC [11]). The study developed, pre-tested and used qualitative and quantitative instruments, namely Key Informant Interview (KII) and Focus Group Discussion (FGD), transect/environmental walk, direct observation on issues of water, sanitation and hygiene (WASH). Gender was mainstreamed into the selection of respondents. The respondents (adult male, female and youths) who were purposively selected included opinion leaders and representatives of traditional institutions in each of the 11 small towns, respectively. For the purpose of the focus group discussion, three groups of people were drawn from each of the small towns; these include male, female and youth representatives.

\section{Results and discussions}

\subsection{Demographic and household characteristics}

Table 1 shows the demographic and household characteristics of the 7 focal local government areas and the 11 communities used in the study. Columns A, B, C, D, E, F, G and H, respectively, show:

(a) Local government areas in which the 11 communities used in the study are located

(b) The population of the 7 local government areas

(c) The names of 11 communities used in the study

(d) The population of the 11 communities

(e) The number of households in the 11 communities

(f) The $\%$ of adult population in the 11 communities

(g) The $\%$ of children population in the 11 communities

(h) The number of compounds in the communities

It can be observed from the table that of the 11 communities, only one (Ajebamidele) has a population of more than 10,000 while the others have between 5,000 and 10,000 inhabitants. Furthermore, it can be noted from the table that the mean compound in the study area was 41 while the average number of households was 939 with Oba-Ile having the highest number of households of 2,865 among the selected 11 communities. The mean adult and children population were 30.9 percent and 69.1 percent, respectively with Masifa-Ile $(75.6 \%)$ being the highest while Oke-Ila with $(57.3 \%)$ has the least. Hence, majority of the population were children (69.1\%) which could be as a result of the absence of the older population at the time of the survey.

With respect to distribution of population between adults and children, it can be noted from the table that the pattern was similar in all the 11 communities as there were more children than adults. This was probably due to the absence of 
Table 1: $\quad$ Demographic and household characteristics of the study area.

\begin{tabular}{|c|c|c|c|c|c|c|c|}
\hline LGAs & Population & Communities & Population & $\begin{array}{l}\text { No of } \\
\mathrm{HHs}\end{array}$ & $\begin{array}{c}\% \text { of } \\
\text { Adult }\end{array}$ & $\begin{array}{c}\% \text { of } \\
\text { Children }\end{array}$ & $\begin{array}{c}\text { No of } \\
\text { Compounds }\end{array}$ \\
\hline (A) & (B) & (C) & (D) & (E) & (F) & (G) & (H) \\
\hline Ife Central & 167,254 & Ajebamidele & 11,732 & 343 & 41.6 & 58.4 & - \\
\hline \multirow[t]{2}{*}{ Olorunda } & \multirow[t]{2}{*}{131,761} & Oba-ile & 5,408 & 2865 & 28.1 & 71.9 & 39 \\
\hline & & Oba-oke & 5,713 & 1649 & 35.6 & 64.4 & 15 \\
\hline \multirow[t]{2}{*}{ Ayedaade } & \multirow[t]{2}{*}{150,392} & Orisumbare & 5,031 & 510 & 21.8 & 78.2 & 23 \\
\hline & & Ilupeju & 5,807 & 580 & 26.7 & 73.3 & 31 \\
\hline \multirow[t]{2}{*}{ Ejigbo } & \multirow[t]{2}{*}{132,641} & Ife-odan & 9,529 & 243 & 25.8 & 74.2 & 106 \\
\hline & & Masifa ile & 5,720 & 114 & 24.4 & 75.6 & 82 \\
\hline Odo-otin & 134,110 & Eekosin & 7,097 & 1,155 & 34.7 & 65.3 & - \\
\hline \multirow[t]{2}{*}{ Oriade } & 148,617 & Owena ijesa & 6,823 & 878 & 29.0 & 71.0 & 25 \\
\hline & & Erinmo Ijesa & 5,633 & 830 & 29.7 & 70.3 & 27 \\
\hline Ifedayo & 37,058 & Oke Ila & 8,007 & 1363 & 42.7 & 57.3 & 18 \\
\hline Total & 901,833 & & 76,500 & 10,530 & 340 & 760 & 366 \\
\hline Mean & 128,833 & & 6,955 & 957 & 31 & 69 & 33 \\
\hline
\end{tabular}

$\mathrm{HHs}=$ Number of households.

older population at the time of the survey, as most of them were away to their farms since the survey was conducted during the peak of farming season. This could also have accounted for the relatively lower population recorded at the time of the survey. The estimated number of households for Ife Odan and Masifa are 243 and 114, respectively with an estimated female population of 59 percent and 57 percent respectively. Ajebamidele, in Ife central LGA has 343 households Of course, it is a well-known fact that the structure of any population determines the need of the inhabitants hence where majority of the population is youth, education and sanitation becomes very important both from the perspective of information dissemination, health and well being.

\subsection{State of water supply}

Table 2 shows the identified sources of water supply in the 11 rural communities used for the study. It can observed from the table that the sources of water supply in the study area include rivers, streams, unprotected hand-dug wells, protected hand-dug wells, boreholes and pipe-borne water.

The table further shows that a total of 132 rivers/streams are available in the 11 rural communities used in the study. Out of these, 136 unprotected wells, 335 protected hands dug wells, 36 boreholes and 6 pipe borne water (stand pipes) that were functioning as at the time of data collection. Oba Ile had the highest number of functioning facilities among the 11 small towns, 64 rivers/streams, 
Table 2: $\quad$ Sources of water supply in the eleven communities used in the study.

\begin{tabular}{|c|c|c|c|c|c|}
\hline Community & $\begin{array}{l}\text { River/ } \\
\text { stream }\end{array}$ & $\begin{array}{c}\text { Unprotected } \\
\text { Hand-dug } \\
\text { well } \\
\end{array}$ & $\begin{array}{l}\text { Protected } \\
\text { Hand- } \\
\text { dug well }\end{array}$ & Borehole & Pipe- borne \\
\hline (A) & (B) & (C) & (D) & (E) & (F) \\
\hline Ife Odan & 3 & 33 & 22 & 6 & - \\
\hline Masifa Ile & 17 & - & 85 & 2 & - \\
\hline $\begin{array}{l}\text { Oke-Ila } \\
\text { Orangun }\end{array}$ & 6 & 1 & 4 & 8 & - \\
\hline Eekosin & 4 & 11 & 24 & 5 & - \\
\hline Ilupeju & 7 & 3 & - & - & - \\
\hline Orisumbare & 2 & - & - & - & - \\
\hline Ajebamidele & 5 & 11 & 21 & 7 & 4 \\
\hline Oba Oke & 16 & 28 & 34 & - & - \\
\hline Oba Ile & 64 & 44 & 86 & 8 & - \\
\hline $\begin{array}{c}\text { Erinmo } \\
\text { Ijesha }\end{array}$ & 5 & 2 & 32 & - & - \\
\hline $\begin{array}{l}\text { Owena } \\
\text { Ijesha }\end{array}$ & 3 & 3 & 27 & - & 2 \\
\hline Total & 132 & 136 & 335 & 36 & 6 \\
\hline Mean & 12 & 12.4 & 30.5 & 3.3 & 0.6 \\
\hline
\end{tabular}

44 unprotected hand-dug wells, 86 protected hand-dug wells serving their water demands. However, most of the protected and unprotected hand-dug wells were constructed and privately owned by some households among the population, as revealed by the Focus Group discussion and Key Informant Interviews. Moreover, it was revealed that most of the available streams in the eleven communities are seasonal and more often than not, dry up during the peak of dry season thereby exposing majority of the rural inhabitants to poor and unreliable sources of water for drinking and cleaning purposes during such periods. Consequently, the inhabitants often become vulnerable to faeco-oral related diseases. In general, in terms of recognizable components of improved access; including accessibility, affordability, and sufficiency, none of the villages under the focus towns can be said to have attained the expected standard.

\subsection{Water supply-demand analysis}

The water supply-demand situation of the study area is examined in this section. Table 3 shows the water supply-demand characteristics in the 7 focal local government areas in which the 11 communities used for the study are located. In the table, columns A, B, C, D, E, F and G respectively show

(a) The LGAs in which the 11 communities are located

(b) The population of the LGAs

(c) The water demand of the LGAs $\left(\mathrm{m}^{3} /\right.$ day) 
(d) The water supply of the LGAs $\left(\mathrm{m}^{3} /\right.$ day)

(e) The water demand deficits of the LGAs $\left(\mathrm{m}^{3} /\right.$ day)

(f) The water usage per capita in the LGAs $\left(\mathrm{m}^{3} /\right.$ day)

(g) The $\%$ of water supply coverage in the LGAs.

Table 3: Water supply-demand characteristics in the 7 focal LGA of the study area.

\begin{tabular}{|c|c|c|c|c|c|c|}
\hline LGA & Population & $\begin{array}{c}\text { Water } \\
\text { Demand } \\
\left(\mathrm{m}^{3} / \mathrm{day}\right)\end{array}$ & $\begin{array}{c}\text { Water } \\
\text { Supply } \\
\left(\mathrm{m}^{3} / \text { day }\right)\end{array}$ & $\begin{array}{c}\text { Water } \\
\text { demand } \\
\text { deficit } \\
\left(\mathrm{m}^{3} / \text { day }\right)\end{array}$ & $\begin{array}{c}\text { Water } \\
\text { Usage } \\
\text { per } \\
\text { capita } \\
\left(\mathrm{m}^{3} / \text { day }\right)\end{array}$ & $\begin{array}{c}\text { \% of } \\
\text { Water } \\
\text { Supply } \\
\text { Coverage }\end{array}$ \\
\hline $\mathbf{A}$ & B & $\mathrm{C}$ & D & $\mathbf{E}$ & $\mathbf{F}$ & G \\
\hline $\begin{array}{c}\text { Ife } \\
\text { Central }\end{array}$ & 167,254 & 10,035 & 4,616 & $\begin{array}{l}5,419 \\
(54 \%)\end{array}$ & 27.52 & 43.5 \\
\hline Olorunda & 13,761 & 7,905 & 4,040 & $\begin{array}{c}3,866 \\
(49 \%)\end{array}$ & 293.60 & 33.3 \\
\hline Ayedaade & 150,392 & 9,027 & 3,068 & $\begin{array}{l}5,959 \\
(34 \%)\end{array}$ & 20.40 & 16.5 \\
\hline Ejigbo & 132,641 & 7,940 & 6,368 & $\begin{array}{l}1,572 \\
(20 \%)\end{array}$ & 48.01 & 14.3 \\
\hline Odo-Otin & 134,110 & 8,047 & 2,977 & $\begin{array}{c}5,070 \\
(63 \%)\end{array}$ & 22.20 & 25.6 \\
\hline Oriade & 148,617 & 8,917 & 1,025 & $\begin{array}{c}7,892 \\
(89 \%)\end{array}$ & 06.89 & 41.2 \\
\hline Ifedayo & 37,058 & 2,223 & 0.497 & $\begin{array}{l}2222.5 \\
(99 \%)\end{array}$ & 0.01 & 19.9 \\
\hline
\end{tabular}

It can be observed from table 3 that the water demand-supply situation in the study area is characterized by a lot of water demand deficits. For instance, Ifedayo recorded a deficit of $99 \%$ while Oriade recorded $75 \%$. Similarly Ejigbo had deficit of $84 \%$ while Ife Central had a deficit of $54 \%$. The above situation, no doubt, has a lot of implications for the sustainable health and well being of the inhabitants and therefore calls for concerted efforts of all the stakeholders to fast-track the provision of water to the affected communities. As in the case in many other parts of the world, the state of water supply in the study area is invariably related to the state of water production In the present study therefore, the actual and potential water production as well as the production efficiencies of the available water systems have been computed using the concept of production efficiency index details of which have been discussed under methodology (see eqn. (1)).

It can be observed from table 4 that out of the 15 the production efficiency of the remaining $10 \%$ falls between $0 \%$ and $33 \%$. For instance, the following water schemes Ilesha, Erin-ijesha, Mokuro and old Ede water schemes recorded a production efficiency index of $0 \%$. From the following analysis therefore it has been showed that none of the 15 water supply systems attained optimum 
Table 4: Efficiency of water supply systems in Osun State, South West, Nigeria.

\begin{tabular}{|c|c|c|c|c|c|}
\hline $\mathbf{S} / \mathbf{n}$ & $\begin{array}{l}\text { Water } \\
\text { supply } \\
\text { system }\end{array}$ & $\begin{array}{l}\text { Raw water } \\
\text { source }\end{array}$ & $\begin{array}{c}\text { Installed capacity } \\
\text { m }^{3} / \text { day (potential } \\
\text { production ) }\end{array}$ & $\begin{array}{c}\text { Actual } \\
\text { (Average) } \\
\text { production } \\
\mathbf{m}^{3} / \text { day } \\
\end{array}$ & $\begin{array}{l}\text { PEI } \\
(\%)\end{array}$ \\
\hline & (A) & (B) & (C) & (D) & (E) \\
\hline 1 & $\begin{array}{c}\text { New Ede } \\
\text { Water works }\end{array}$ & River & 180,000 & 45,000 & 25 \\
\hline 2 & $\begin{array}{c}\text { Eko-Ende } \\
\text { Water } \\
\text { Scheme }\end{array}$ & River & 13,100 & 3,799 & 29 \\
\hline 3 & $\begin{array}{c}\text { Ilesha Water } \\
\text { Scheme }\end{array}$ & River & 2,700 & 0 & 0 \\
\hline 4 & $\begin{array}{c}\text { Erin-Ijesha } \\
\text { Waterfall } \\
\text { Scheme }\end{array}$ & Spring & 227 & 0 & 0 \\
\hline 5 & $\begin{array}{l}\text { Esa odo } \\
\text { Water } \\
\text { Scheme }\end{array}$ & River & 4,990 & 1,647 & 33 \\
\hline 6 & $\begin{array}{c}\text { Ipetu-ijesha } \\
\text { Water } \\
\text { Scheme }\end{array}$ & River & 2,180 & 436 & 20 \\
\hline 7 & $\begin{array}{l}\text { Iwo Water } \\
\text { Scheme }\end{array}$ & River & 9,080 & 908 & 10 \\
\hline 8 & $\begin{array}{l}\text { Ila Water } \\
\text { Scheme }\end{array}$ & Stream & 3,480 & 1,914 & 55 \\
\hline 9 & $\begin{array}{l}\text { Asi Water } \\
\text { Scheme }\end{array}$ & Stream & 944 & 113.28 & 12 \\
\hline 10 & $\begin{array}{c}\text { Asaba } \\
\text { Artesian } \\
\text { Well }\end{array}$ & River & 288 & 201.60 & 70 \\
\hline 11 & $\begin{array}{c}\text { Igbajo Water } \\
\text { Scheme }\end{array}$ & Boreholes & 1,000 & 500 & 50 \\
\hline 12 & $\begin{array}{l}\text { Ifetedo } \\
\text { Water } \\
\text { Scheme }\end{array}$ & Stream & 360 & 216 & 60 \\
\hline 13 & $\begin{array}{l}\text { Mokuro } \\
\text { Water } \\
\text { Scheme }\end{array}$ & Stream & 1,000 & 0 & 0 \\
\hline 14 & $\begin{array}{c}\text { Ifewara } \\
\text { Water } \\
\text { Scheme }\end{array}$ & Stream & 120 & 102 & 85 \\
\hline 15 & $\begin{array}{l}\text { Old Ede } \\
\text { Water } \\
\text { Scheme }\end{array}$ & River & 20,000 & 0 & 0 \\
\hline
\end{tabular}

PEI $=$ Production Efficiency Index. 
production. The analysis thus showed that the water supply-demand situation of the area is characterized by a lot of water demand deficits with a substantial percentage of the population being impacted by water demand deficits.

No doubt, the water supply-demand deficits translate to acute water shortages which in turn affect the state of sanitation and hygiene in the study area. Apart from its impact on health, inadequate water supply in the area has a lot of socioeconomic implications. For instance, poor access to water often condemn women and children to spend hours in water collection thus denying them of time that could instead have been utilized for income generation and education especially for female children. Given the importance of water availability and accessibility to sustainable human development the need to frontally confront the associated challenges cannot be over-emphasized.

\subsection{Water supply-demand projections}

In order to further examine the water supply-demand situation of the study area, the future water supply-demand characteristics of the 7 focal local government areas were also analyzed in relation to the projected population. Table 5 shows the water supply-demand projection up to year 2015. Columns A, B, C, D, E, F, $\mathrm{G}$ and $\mathrm{H}$ respectively show

(a) The LGAs in which the 11 communities are located

(b) The population of the LGAs

(c) The projected population of the LGAs

(d) The water demand in the LGAs $\left(\mathrm{m}^{3} /\right.$ day)

(e) The projected water demand of the LGAs $\left(\mathrm{m}^{3} /\right.$ day)

(f) The water demand deficit ( $\mathrm{m}^{3} /$ day)

(g) The water supply in the LGAs. $\left(\mathrm{m}^{3} /\right.$ day)

(h) The projected water demand deficit in $\left(\mathrm{m}^{3} /\right.$ day).

Table 5: Water supply-demand projections.

\begin{tabular}{|c|c|c|c|c|c|c|c|}
\hline LGA & $\begin{array}{c}\text { Population } \\
\mathbf{( 2 0 0 8 )}\end{array}$ & $\begin{array}{c}\text { Projected } \\
\text { Population } \\
\mathbf{( 2 0 1 5 )}\end{array}$ & $\begin{array}{c}\text { Water } \\
\text { Demand } \\
\mathbf{m}^{\mathbf{3}} / \mathbf{d a y} \\
\mathbf{( 2 0 0 8 )}\end{array}$ & $\begin{array}{c}\text { Projected } \\
\text { water } \\
\text { Demand } \\
\mathbf{m}^{\mathbf{3}} / \mathbf{d a y} \\
\mathbf{( 2 0 1 5 )}\end{array}$ & $\begin{array}{c}\text { Water } \\
\mathbf{d e m a n d} \\
\mathbf{d e f i c i t} \\
\mathbf{c} \\
\mathbf{( 2 0 0 8 )}\end{array}$ & $\begin{array}{c}\text { Water } \\
\text { Supply } \\
\mathbf{m}^{\mathbf{3}} / \mathbf{d a y} \\
\mathbf{( 2 0 0 8 )}\end{array}$ & $\begin{array}{c}\text { Projected } \\
\mathbf{w a t e r} \\
\mathbf{D e m a n d} \\
\mathbf{d e f i c i t} \\
\mathbf{m}^{\mathbf{3}} / \mathbf{d a y} \\
\mathbf{( 2 0 1 5 )}\end{array}$ \\
\hline $\mathbf{A}$ & $\mathbf{B}$ & $\mathbf{C}$ & $\mathbf{D}$ & $\mathbf{E}$ & $\mathbf{F}$ & $\mathbf{G}$ & $\mathbf{H}$ \\
\hline Ife central & 167,254 & 204,049 & 10,035 & 12,243 & 5,419 & 4,616 & 7627 \\
\hline Olorunda & 131,761 & 160,748 & 7,906 & 9,629 & 3,866 & 4,040 & 5,589 \\
\hline Ayedaade & 150,392 & 183,478 & 9,024 & 11,009 & 5,956 & 3,068 & 7,941 \\
\hline Ejigbo & 132,341 & 161,456 & 7,940 & 9,687 & 1,572 & 6,368 & 3,449 \\
\hline Odo-otin & 134,110 & 163,614 & 8,047 & 9,817 & 5,070 & 2,977 & 6,840 \\
\hline Ori-ade & 148,617 & 181,312 & 8,917 & 10,879 & 7,892 & 1,025 & 9,854 \\
\hline Ifedayo & 37,058 & 45,210 & 2,223 & 2,713 & $2,222.5$ & 0.497 & $2,712.5$ \\
\hline
\end{tabular}

*Water demand deficit projections are based on 'business as usual' scenario (i.e. 2008 water supply figures). 
It can be observed from the table that in, general the projected water supplydemand situation of the study area is characterized by increased water demand deficits. For instance, the water demand deficit for Ife central which was 5,419 $\left(\mathrm{m}^{3} /\right.$ day) in 2008 would increase to $7,627\left(\mathrm{~m}^{3} /\right.$ day) in 2015 similarly, the water demand deficit for Ayedaade which was 5,956 ( $\mathrm{m}^{3} /$ day) in 2008 would increase to $7,941\left(\mathrm{~m}^{3} /\right.$ day $)$ in 2015 . This situation can be attributed in part, to the relatively low production efficiency of the water supply systems in the area.

\subsection{Water supply, sanitation and hygiene}

Table 6 shows the distribution of access to improved sanitation in the study area. The table shows that, Ejigbo, Odo-Otin and Ifedayo LGAs are the most affected, with $26.8,11.8$ and 6.8 percent of the population respectively having access to sanitation. This shows the probable relationship between water sufficiency and access to sanitation, as the most vulnerable among the LGAs were also found to be negatively affected in terms of sanitation.

Table 6: $\quad$ Access to improved sanitation in the study area.

\begin{tabular}{|c|c|c|}
\hline LGA & Population & $\begin{array}{c}\text { Actual \% with } \\
\text { Access to } \\
\text { sanitation* }\end{array}$ \\
\hline Ife Central & 167,254 & 81.3 \\
\hline Olorunda & 131,761 & 57.9 \\
\hline Ayedaade & 150,392 & 59.9 \\
\hline Ejigbo & 132,641 & 26.8 \\
\hline Odo Otin & 134,110 & 11.8 \\
\hline Oriade & 148,617 & 54.1 \\
\hline Ifedayo & 37,058 & 6.8 \\
\hline
\end{tabular}

*Calculated as number of households with access to safe sanitation in the LGA divided by the total number of HHs randomly surveyed x 100 .

\section{Conclusion and recommendations}

The study has revealed that the water supply situation in the rural communities studied is characterized by a lot of water demand deficits and this has farreaching socio-economic and health implications for the inhabitants of the area. It was also revealed that very few rural communities in the area could boast of safe sources of water supply, hence, they have to depend on traditional sources of water supply such as rain, springs, streams, ponds and hand-dug wells.

Arising from the findings of this study, the following suggestions are made. First, an appropriate water policy must be put in place by government to address holistically water supply and sanitation issues particularly, as they affect the rural areas. Secondly, there is an urgent need to ensure that existing water supply systems in area function optimally as this will boost water availability and thus reduce significantly, the current water demand deficits in the area. 
Given the dispersed nature of the settlements which makes house-to-house water connections expensive, community deep wells or bore holes are suggested particularly, for areas with adequate ground water resources. It is pertinent to stress that adequate technical/geo-physical surveys should guide the location of such facilities. It also suggested that an effective template for monitoring water supply facilities in which the communities are involved should be developed.

\section{Acknowledgements}

The support given by the European Union Water Supply and Sanitation Sector Reform Programme Unit (EU-WSSSRP) of the Ministry of Water Resources and Rural Development, Osun State, Nigeria is gratefully appreciated. Also, I am grateful to Prof. S. O. Ojo, Department of Geography, University of Lagos, Nigeria for his comments and suggestions towards the completion of the study.

\section{References}

[1] ADB/UNO/HABITAT for a Better Future, (2008) Water and For Developing Clean, Healthy Cities. Seminar Report from the World Urban Forum 4, Naijing, China

[2] Cecilia, Martisen, (2008); The Urban Water and Sanitation Challenge 2008.

[3] Madeleen W. and Kamminga (2003) Water Supply, Sanitation, Hygiene and HIV/AIDS: the unrecognized links, Aids Analysis Africa 14(1).

[4] USAID (1999) BHR/DFDA Annual Report, FY. US Agency for International Development, Washington D.C, www.usaid.govt/our_work/ humanitarianassistance/disaster assistance/publication/annual report.

[5] The Economist Sept. 7-13, 2002.

[6] Ayoade J.O. (1988) Tropical Hydrology and Water Resources; MacMillan, Ibadan, Nigeria.

[7] Ojo Olukayode, (1997) Water Environment and Sustainable Development In Tola Adejuwon and A.O.K Noah (Eds) Perspectives on Education, Women and Environment in Nigeria; Central Educational Services, Lagos Chapter 42 PP 279-286

[8] Ojo Olukayode, (2000) Social Issues of Sustainable Water Supply Management in Tayo Odumosu (Ed) Social Problems and Social Work in Nigeria, Centre for Planning Studies, LASU.

[9] Osun State Report of the National Baseline Survey, (2007).

[10] Ojo Olukayode, (1993): Towards Optimization of the Water Resources Potentials of Lagos State: Problems and Prospects. LASU Journal of Social Science Vol. 3.

[11] National Population Commission Census Report(2007) 